\title{
Comparative Analysis of Physical-Mechanical Properties of Natural and Recycled Aggregate Concretes
}

\author{
Barbara Sadowska-Buraczewska1", Justyna Kujawska² \\ 1 Faculty of Civil Engineering and Environmental Sciences, Bialystok University of Technology, ul. Wiejska 45 A, \\ 15-351 Bialystok, Poland \\ 2 Faculty of Environmental Engineering, Lublin University of Technology, ul. Nadbystrzycka 40B, 20-618 Lublin, \\ Poland \\ * Corresponding author's email: barbara.sadowska@pb.edu.pl
}

\begin{abstract}
Research on the use of construction and demolition waste as recycled aggregate for the production of new concrete has confirmed that they are environmentally friendly and constitute an alternative method of waste management. However, contrary to conventional concrete, no large applications of concrete made with recycled concrete have been made and there is still the literature studies of recycled aggregate properties are different, which indicates the need for further research on the properties of cements from waste. This paper presents and compares the results of a laboratory study on the properties of ordinary concrete (BZ), high-strength concrete (BWW), recycled aggregate concrete (REC). The tensile and compressive strength, modulus of elasticity of these concentrates were marked. The research results proved that the compressive strength of the concrete with recycled aggregate, compared with high-performance concrete, is much lower, but only slightly lower than for ordinary concrete. In turn, the tensile strength of the concrete with recycled aggregate is lower than that of high-performance concrete and ordinary concrete. These values, in the case of the compressive strength are as follows: REC $-52 \mathrm{MPa}$; BWW $-68 \mathrm{MPa}$; $\mathrm{BZ}-25 \mathrm{MPa}$, whereas for the tensile strength, they reach: REC - 4 MPa, BWW - 6 MPa, BZ - 5.1 MPa. Statistical analysis showed that the given parameters of the analysed concretes are indeed statistically different. Obtained results indicate that recycled aggregate may be aggregate of standard value and good mechanical properties, even better than of ordinary concrete. The application of recycled aggregate is considered to be a new approach in balanced construction and a superb solution to protect the environment.
\end{abstract}

Keywords: sustainable development, compressive strength, tensile strength, recycled aggregate concretes

\section{INTRODUCTION}

Globally, the construction industry has the greatest share in a carbon footprint and is the major consumer of natural resources [1]. Moreover, the aforementioned industry is responsible for approximately $25-30 \%$ of global emissions of all waste including concrete, bricks, plaster, timber, glass, metal, plastic, solvents, asbestos, and mined dirt [2]. In 2018, in Poland, there were 3774 thousand tonnes of construction waste produced $[3,4]$ which extend to increasing prices and the growing dependence on foreign suppliers. The situation is particularly unfavorable in the construction sector, which is among the most resource-and energy-consuming areas of the economy. This paper juxtaposes the situation of Polish construction industry in the context of the national economy with the context of the evolving EU policies promoting green solutions. The resulting changes in Polish legislation, industry and society are identified. The implementation of selected Circular Economy (CE. Construction waste is considered to be produced not only during the construction of new buildings but also during the demolition or reconstruction of existent buildings. The remaining materials used for the construction are disposed and new materials are obtained, for new construction $[5,6,7,8]$. 
A part of that waste is being stored at storage yards, whereas others are placed in large quantities in reservoirs, drainage ditches, and wastelands, located nearby the residential areas. The physical and chemical properties of that waste indicate on its possible hazardous impact on the environment $[9,10]$. Besides, accumulated waste block available lands which otherwise might have been used for other purposes.

Effective use in new concrete of recycled aggregate obtained from concrete may contribute to a limitation of storage of waste and concurrently decrease the demand on natural aggregate - both constitute a vital environmental aspect, and should be considered in responsible, balanced management [11]. This would also be an essential contribution to solving one of the major scopes of the UN's 2030 agenda on balanced consumption and production: balanced consumption and production management. The aim is focused on economic growth based on the effective management of resources and low environmental degradation together with an improvement in humans' prosperity. It may be reached by a change in the direction of more balanced consumption of the resources and improved production processes [12].

Furthermore, waste reuse is imposed by the legislation of the European Union. The EU waste directive 2008/98/EC requires member states to recycle $70 \%$ of their non-hazardous CDW as raw materials by 2020 . However, the current recycling rate reaches only approximately $46 \%[13,14,2]$.

Annually, the construction industry produces 75 million tonnes of concrete rubble [15], 52\% (weight) of that waste is concrete, which may be recycled to the recycled aggregate concrete (REC) used as a substitute for natural aggregate in concrete production $[16,17,18]$. Reusing of aggregate has become a subject of various research as well as using recycled materials has started to be popularised. Nevertheless, current specifications and experience seem to be not enough to support and encourage to recycle of construction and demolition waste in parts of the world [19]. Moreover, there are still technical issues, including for instance shortage of research on the interfacial transition zone between cement mortar and recycled aggregate.

According to the research, the physical properties of recycled aggregates (REC) depend on the quantity and quality of used cement mortar $[20,21]$. It is observed that mechanical properties (compressive, fracture, and tensile strengths,
Young's modulus) of the recycled aggregate concrete are decreasing with an increase in the percentage of natural aggregate content (NA) [22, 23]. What is more, mechanical properties of recycled concrete are complex. This is influenced by the geometry and mechanics of aggregate properties, as well as two different interfacial transition zones (one is located between the original natural aggregate and the old mortar, the second one between the old and new mortars). Certainly, it is slightly different in the case of natural aggregate concrete, where only one interfacial transition zone occurs [24].

In the literature has been described consensus on the application of recycling-originating aggregates in concrete production; together with the increase in the level of exchange the compressive strength of concrete decreases. It has been observed [25], that considering practical matter the level of exchange at approximately $30 \%$ for coarse recycled aggregate or at $20 \%$ for fine aggregate has a marginal impact on the development of the strength of concrete. Nevertheless, the strength is decreasing gradually, together with an increase in the level of recycled aggregate (RA) exchange [20, 26, 27, 28, 29]. As an addition, it has been also noticed that the average strength of concrete consisted of $100 \%$ coarse recycled aggregate or $50 \%$ fine REC is between $20 \%$ to $30 \%$ lower than for adequate natural aggregate concrete $[23,27]$.

Recycled aggregate has different properties than natural aggregates, therefore they behave differently in concrete mixtures [30]. Compressive strength, tensile strength and modulus of elasticity are the most effective properties of concrete affecting its performance properties. The studies of the recycled aggregate properties they are different. The compressive strength of REC is generally $10-30 \%$ lower than that of natural aggregate concrete $[31,32,33]$. However, other researchers observed that the compressive strength of the concrete remained unchanged or slightly increased when NA was replaced by REC by up to $25 \%$ [6]. There are also known methods of increasing the compressive strength of REC, such as usage of admixtures [34, 35, 36, 37], increasing the cement content [38], use of plasticizers and mixing methods [39] etc. Moving on to literature studies tensile strength of REC shows that tensile strength decreases with increase in reccycled aggregate (RA) replacement ratio [34]. Bairagi et al. [40] reported that the tensile strength of REC 
was $6 \%, 10 \%$ and $40 \%$ lower than normal concrete when REC was made with $25 \%, 50 \%$ and $100 \%$ replacement for RA. Other studies showed that the REC tensile strength for an exchange rate of up to $30 \%$ is the same or even exceeds the tensile strength of the original concrete [6]. They are similarly described with the values of the modulus of elasticity. The modulus of elasticity has been negatively affected by the inclusion of RA [41, 39, 42, 43]. Kou et al. [42] showed that the modulus of elasticity decreased by $12.6 \%$ for the $50 \%$ replacement rate and by $25.2 \%$ for the $100 \%$ replacement rate. However, Pereira et al. [39] observed that the modulus of elasticity was almost unchanged when the replacement ratio increased to $30 \%$. Literature studies indicate that various factors have an impact on the properties of concrete made of recycled aggregate, which indicates the importance of further testing of various proportions of recycled waste additives or mineral additives so that they can be used as required.

Popularisation of the results of research on the application of recycled materials for concrete production and acquaintance with their properties are important. The aim of this paper is to assess the possibilities of using concrete as aggregate in new concrete mixtures. The article has been conducted a comparison of properties of various concretes: natural, with the addition of natural aggregate, and with the addition of recycled aggregate. Statistical analysis has been made to determine the significance of variability of physicalmechanical properties of the analysed concretes.

The article consists of four sections. Section 1 presents analysis of the literature in the area. Section 2 describes the methods used. Section 3 presents the compressive strength, tensile strength, modulus of rigidity and modulus of elasticity tested concentrates: ordinary concrete (BZ), highstrength concrete (BWW), recycled aggregate concrete (REC). The results were compared with each other. The paper ends with Section 4, which contains final conclusions.

\section{MATERIALS AND METHODS}

For mixtures Portland cement CEM I 32,5 R and quartz sand $(0-0.025 \mathrm{~mm} ; 0.025-0.5 \mathrm{~mm} ; 0.5$ $1 \mathrm{~mm} ; 1-2 \mathrm{~mm}$ ) were used. Technical parameters of used cement are presented in Table 1.

Three concrete mixtures have been prepared: ordinary concrete (BZ), high-strength concrete (BWW), recycled aggregate concrete (REC) which compositions are drawn up in Table 2. As it is presented in Table 2, BWW and REC mixtures vary in the material of coarse aggregate. In the BWW mixture basalt gravel has been used, whereas in the REC coarse aggregate was composed of concrete rubble from the construction elements with the concrete resistance corresponding to C16/20 class. The concrete mix was prepared using the aggregate fractions from the smallest 0-2 $\mathrm{mm}$, through $2-4 \mathrm{~mm}$ and $4-8 \mathrm{~mm}$, in order to obtain. C16/20 2/4 is the aggregate fraction with a grain diameter from 2 to $4 \mathrm{~mm}$ and C16/20 4/8 is the aggregate fraction with a grain diameter from 4 to $8 \mathrm{~mm}$. The chemical composition of substrates used in mixtures is shown in Table 3.

To concrete mixtures, BWW and REC silica fume and superplasticizer Sika ViscoCrete 20 Gold have been also added. Silica fume is a powdered additive to concrete, in which grains are ultra-fine $(0.1 \mu \mathrm{m})$. It aims to increase water resistance, pumpability, and resistance of concrete to chemical corrosion. A superplasticizer is an additive aiming at a reduction of water required to prepare concrete. Properties of the superplasticizer are presented in Table 4.

Table 1. Composition of CEM II B-V 32,5R [44]

\begin{tabular}{|l|c|c|}
\hline \multicolumn{1}{|c|}{ Properties } & Unit & CEM II B-V 32,5R \\
\hline Specific surface & $\left(\mathrm{cm}^{2} \cdot \mathrm{g}^{-1}\right)$ & 4237 \\
\hline Initial setting time & $(\mathrm{min})$ & 243 \\
\hline Compressive strength & $(\mathrm{MPa})$ & 20.3 \\
\hline$\bullet$ after 2 days & $(\mathrm{MPa})$ & 45.7 \\
$\bullet$ after 28 days & $\left(\mathrm{g} \cdot \mathrm{cm}^{-3}\right)$ & 2.83 \\
\hline Density & $(\%)$ & 2.28 \\
\hline $\mathrm{SO}_{3}$ content & $(\%)$ & 0.06 \\
\hline $\mathrm{Ch}^{\text {Oride ion content }}$ & $(\%)$ & 1.09 \\
\hline $\mathrm{Na}_{2} \mathrm{O}$ content & $(\%)$ & \\
\hline
\end{tabular}


Table 2. Composition of concentrate mixtures

\begin{tabular}{|c|c|c|c|c|}
\hline Components & Unit & BZ & BWW & REC \\
\hline Cement CEM II B-V 32,5R & $\mathrm{kg} \cdot \mathrm{m}^{-3}$ & 270 & 500 & 500 \\
\hline Water & $\mathrm{kg} \cdot \mathrm{m}^{-3}$ & 178 & 143 & 143 \\
\hline Sand $0 / 2$ & $\mathrm{~kg} \cdot \mathrm{m}^{-3}$ & 788 & - & - \\
\hline Gravel 2/8 & $\mathrm{kg} \cdot \mathrm{m}^{-3}$ & 488 & - & - \\
\hline Gravel 8/16 & $\mathrm{kg} \cdot \mathrm{m}^{-3}$ & 600 & - & - \\
\hline Superplasticizer & $\mathrm{kg} \cdot \mathrm{m}^{-3}$ & 2.21 & 7.50 & 7.50 \\
\hline $\begin{array}{l}\text { Fine aggregate: } \\
\text { - sand } 0 / 0,25\end{array}$ & $\mathrm{~kg} \cdot \mathrm{m}^{-3}$ & - & 36 & 36 \\
\hline - sand $0,025 / 0,5$ & $\mathrm{~kg} \cdot \mathrm{m}^{-3}$ & - & 108 & 108 \\
\hline - sand $0,5 / 1,0$ & $\mathrm{~kg} \cdot \mathrm{m}^{-3}$ & - & 216 & 216 \\
\hline - sand $1,0 / 2,0$ & $\mathrm{~kg} \cdot \mathrm{m}^{-3}$ & - & 240 & 240 \\
\hline $\begin{array}{l}\text { Coarse aggregate: } \\
\text { - basalt gravel } 2 / 4\end{array}$ & $\mathrm{~kg} \cdot \mathrm{m}^{-3}$ & - & 530 & - \\
\hline - basalt gravel $4 / 8$ & $\mathrm{~kg} \cdot \mathrm{m}^{-3}$ & - & 700 & - \\
\hline - concrete rubble C16/20 2/4 & $\mathrm{kg} \cdot \mathrm{m}^{-3}$ & - & - & 530 \\
\hline - concrete rubble C16/20 4/8 & $\mathrm{kg} \cdot \mathrm{m}^{-3}$ & - & - & 700 \\
\hline Silica fume & $\mathrm{kg} \cdot \mathrm{m}^{-3}$ & & 50 & 50 \\
\hline
\end{tabular}

Table 3. Chemical composition of substrates used in concrete mixtures [45]

\begin{tabular}{|l|c|c|c|c|c|c|c|c|}
\hline \multicolumn{1}{|c|}{ Compositions } & $\mathrm{SiO}_{2}$ & $\mathrm{Al}_{2} \mathrm{O}_{3}$ & $\mathrm{FeO}$ & $\mathrm{MgO}$ & $\mathrm{CaO}$ & $\mathrm{TiO}_{2}$ & $\mathrm{~K}_{2} \mathrm{O}$ & Other alkaline compounds \\
\hline Basalt & 48.5 & 13.8 & 10.5 & 12.2 & 10 & 0.9 & 0.1 & 4.0 \\
\hline Recycled aggregate & 26.60 & 23.22 & 2.40 & 2.49 & 35.25 & 0.33 & 3.21 & 6.5 \\
\hline Sand & 95.2 & 2.0 & 0.6 & & 0.45 & & & \\
\hline Silica fume & 90 & 0.4 & 0.4 & & 1.6 & & 2.2 & 1.9 \\
\hline
\end{tabular}

Table 4. Properties of the superplasticizer [46]

\begin{tabular}{|l|c|}
\hline \multicolumn{1}{|c|}{ Properties } & Superplasticizer \\
\hline Aspect & Light brown liquid \\
\hline Relative density at $25 \%\left(\mathrm{~g} \cdot \mathrm{cm}^{-3}\right)$ & 1.08 \\
\hline $\mathrm{pH}$ & $\geq 6$ \\
\hline Chloride ion content (\%) & $<0.2$ \\
\hline Expected water reduction (\%) & $>20$ \\
\hline
\end{tabular}

\section{Test method}

The research methodology showed on flowchart (Figure 1). The properties of concentrates were measured after 7, 14, 28 days. The analyses repeated three times. The samples were cured in a constant temperature chamber $\left(23 \pm 2{ }^{\circ} \mathrm{C}\right)$ and relative humidity $(95 \pm 5 \%)$. Table 5 shows the tests performed.

Non-destructive concrete tests were performed using a Schmidt hammer to determine the durability of concrete. Tensile and compressive strength tests were conducted in the Laboratory of PSW in Biala Podlaska (Poland) using computer-controlled press CONTROLS, model 50-C7022. To determine Young's modulus and shear modulus for concrete CONTROLS C311-R device was used.

\section{Statistical analysis}

When processing the results of the iterative tests, the arithmetic means and standard deviations of the means were calculated. Obtained results were then tested for normality using the Shapiro-Wilk test [50].

To assess the significance of differences between average values, statistical analyses based on a multiple comparison Tukey's test, with a fixed significance level $\alpha=0.05$. The test facilitated performing a detailed comparative analysis of average values, via isolation of statistically homogeneous average groups (so-called Tukey homogeneous groups) defined by literal indicators. Average values of particular parameters defined for compared data and marked by the same letter indicate their affiliation to a statistically homogeneous group, namely, there is no statistically significant difference between them.

In a course of describing correlations between tested variables, linear correlation matrices between pairs of variables were designated, and their strength is expressed via the value of r-Pearson coefficient. For interpretation of the results of correlation, tests were used criteria of the strength of dependence adopted by Bam et al. 


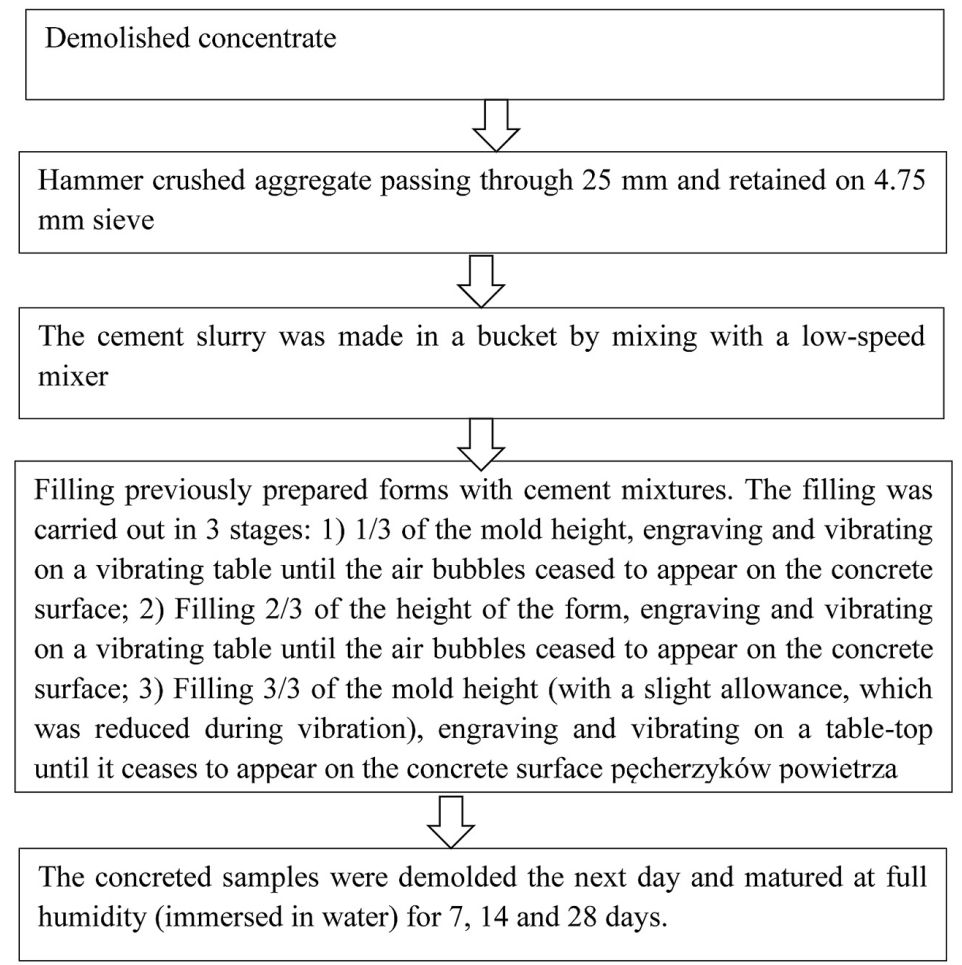

Figure 1. Concrete preparation

Table 5. Tests performed to study the properties of concrete

\begin{tabular}{|l|l|l|}
\hline \multicolumn{1}{|c|}{ Test } & \multicolumn{1}{|c|}{ Standards } & Form and Sample Dimensions \\
\hline Compressive strength & PN-EN 12390-3:2011 (47) & Cuboid: $\varnothing 40 \times 40 \times 160 \mathrm{~mm}$ \\
\hline Tensile splitting strength & UNE-EN 12390-6:2009 (48) & Cuboid: $\varnothing 40 \times 40 \times 160 \mathrm{~mm}$ \\
\hline Static modulus of elasticity in compression & UNE 83316:1996 (49) & Cylindrical: $\varnothing 150 \times 300 \mathrm{~mm}$ \\
\hline
\end{tabular}

(2011), which assume that correlation coefficient $r>0,7$ indicate a strong correlation between two parameters, whereas values between $0,5-0,7$ indicate moderate correlation [51].

\section{RESULTS AND DISCUSSION}

The mean values, the standard error for all analysed concretes on the 28 days concretes are listed in Table 6. Figure 2 and 3 present the photographs of the tested samples during and after testing of the mechanical properties.

\section{Statistical analysis}

Values of the Shapiro-Wilk test of normality for tested concretes after 28 days are presented in Table 7. All the variables were observed to have skewness- and kurtosis-to-standard error ratios lying within the -2 to +2 range, indicating no significant deviation from a normal distribution [50]. Normality for all the variables is also confirmed by obtained Shapiro-Wilk p-values, all of which were over $5 \%$.

Conducted test Tukeya which aims at measuring the impact of tested concretes on properties of concrete has proved that aggregates had a statistically significant influence on the majority of examined variables ( $p$-value $<5 \%$ ).

\section{Compressive strength}

The distntive property of concrete is its compressive strength, other are flexural/tensile strength, durability, permeability, and stiffness. A change in compressive strength usually causes a proportional change in other properties. This also applies to recycled concrete. The compressive strength of each concrete, including recyclingoriginated, is dependent on multiple factors, especially on the water-binder ratio $(\mathrm{w} / \mathrm{b})$, but also on a type of used aggregate, proportion of mixing, properties of used additives, and the age of concrete; for recycled aggregate concretes vital would be also various properties of the material 
a)

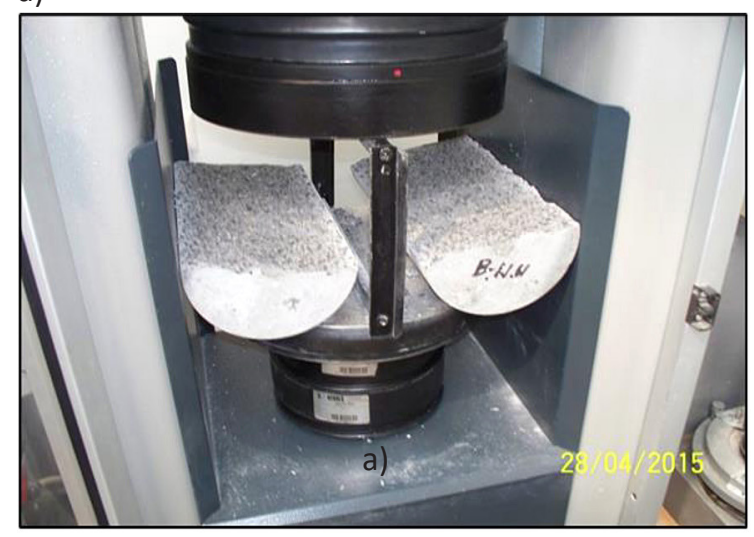

b)

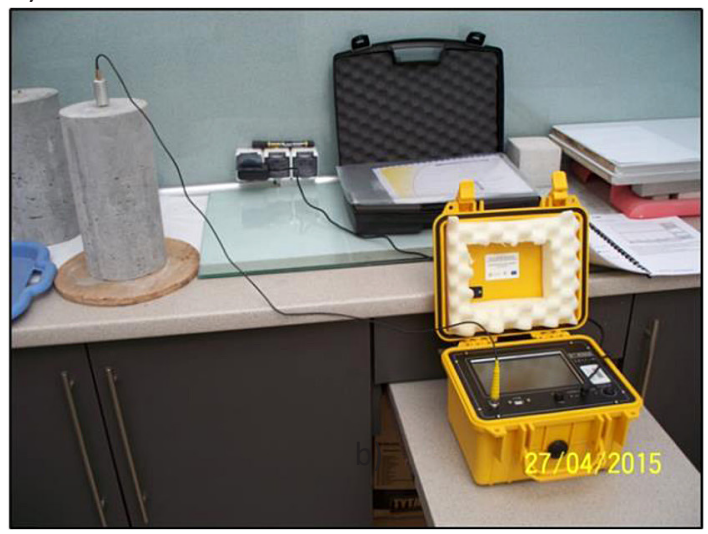

Figure 2. Samples during testing of the (a) dynamic modulus of elasticity with a sensor mounted on a cylindrical specimen; and (b) dynamic modulus of elasticity

a)

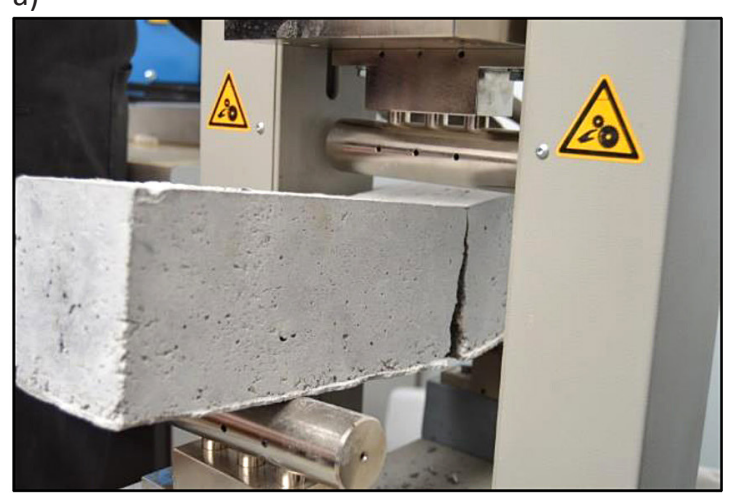

b)

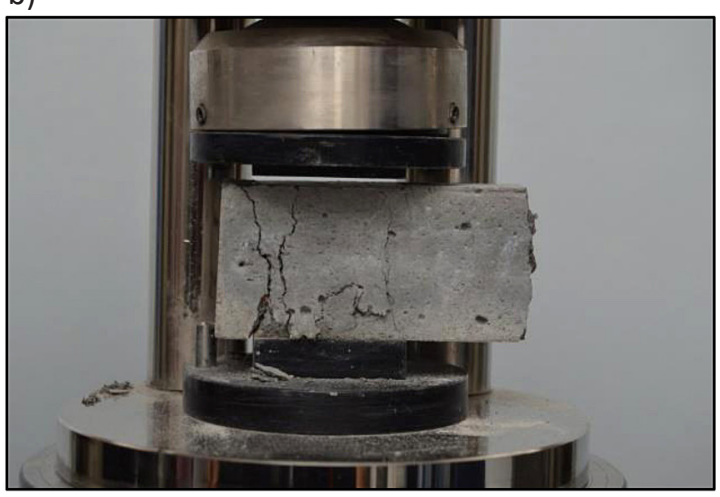

Figure 3. Cubic samples after testing of the (a) tensile strength and (b) compressive strength

Table 6. Compressive, tensile strength, modulus of elasticity for the 28 days concretes $(4 \times 4 \times 16 \mathrm{~cm})$, with statistical parameters

\begin{tabular}{|l|c|c|}
\hline \multicolumn{1}{|c|}{ Concentrate } & Mean & Standard error (\%) \\
\hline BZ & 22 & 1.28 \\
\hline BWW & 69.07 & 0.77 \\
\hline REC & 49.08 & 1.12 \\
\hline \multicolumn{3}{|c|}{ Compressive strength (MPa) } \\
\hline BZ & Tensile strength (MPa) & 0.07 \\
\hline BWW & 3.98 & 0.23 \\
\hline REC & 5.99 & 0.10 \\
\hline Elastic modulus (GPa) & 5.22 & 1.34 \\
\hline BZ & & 2.49 \\
\hline BWW & 31.77 & 1.98 \\
\hline REC & 37.27 & 31.91 \\
\hline
\end{tabular}

used to recycle [52]. Compressive strength of aggregate specified for days 7, 14, 28. Results are presented in Figure 4.

As a result of testing $4 \times 4 \times 16 \mathrm{~cm}$ beams on compressive strength, it was observed that highstrength concrete after 7 days reached $68 \%$ higher strength than concrete with $50 \%$ recycled aggregate. After 14 days the difference decreased to $53 \%$, and for the sample tested after 28 days reached $41 \%$. The strength of ordinary concrete in three testing terms oscillates near $45 \%$ of concrete with $50 \%$ recycled aggregate strength. Previous 
Table 7. Shapiro-Wilk normality test

\begin{tabular}{|l|c|c|c|}
\hline \multicolumn{1}{|c|}{ Parameter } & Compressive strength (MPa) & Tensile strength (MPa) & Elastic modulus (GPa) \\
\hline Skewness/standard error & -0.20 & -0.37 & 0.53 \\
\hline Kurtosis/standard error & 1.03 & -1.49 & 1.03 \\
\hline Shapiro-Wilk p-value & 0.06 & 0.07 & 0.10 \\
\hline
\end{tabular}

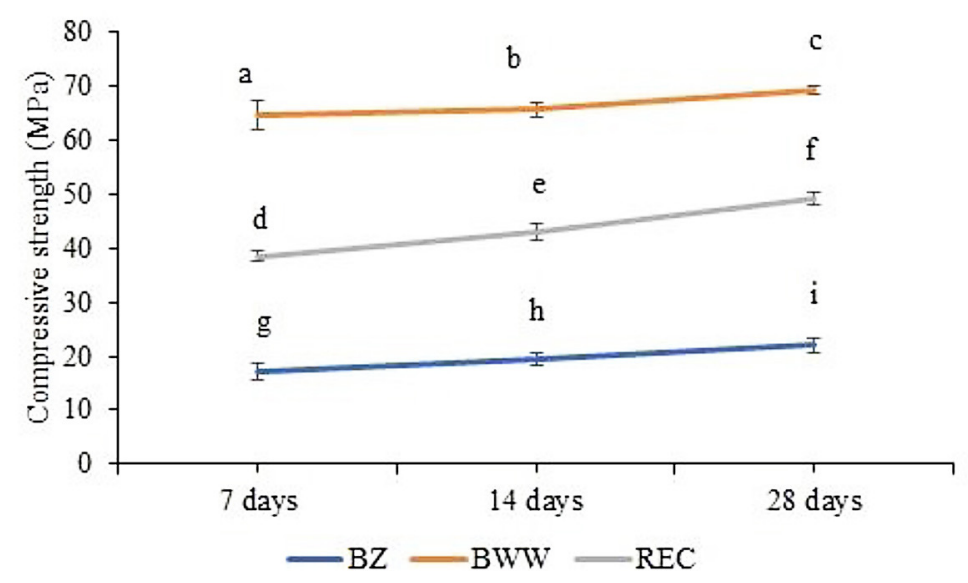

Figure 4. Concrete compressive strength over time. The water-cement ratio for concretes equaled: BZ- 0.47; BWW -0.29 ; REC -0.32 .

studies showed that concretes with $100 \%$ of recycled aggregate had compressive strength after $7,14,28$ days lower by $43 \%, 35 \%, 43 \%$, respectively, than basalt aggregates (45). Kessal et al. suggested that the decrease of the compressive strength of REC (100\% replacement) is about $19 \%$ compared to basalt aggreagates [53].

Conducted post hoc comparison using Tukey's significant difference test proved that obtained values of compressive strength for all examined aggregates on each measurement day are significantly different.

A decrease in values of compressive strength of recycled concretes has been also proved in tests of other researchers. Sagoe-Crentsil et al. (2001) have proved that resistance values of concrete with $23 \%$ additive of recycled aggregate was $5 \%$ lower than in a case of compared natural aggregate concrete [54]. On the other hand, Gomez-Soberón (2002) assumed decreasing by $11 \%$ compressive strength between samples made of $100 \%$ recycled aggregate only regarding concretes made from the natural aggregate. However, when an exchange of natural aggregate reached $30 \%$, the compressive strength decreased by $5 \%[55]$. Malešev proved that values of compressive strength of natural aggregate concretes with additives of natural coarse and recycled fine aggregates reaching up to $50 \%$ is lower than of natural aggregates concrete, which led to the elimination of such combination from the practical application [56].

\section{Tensile strength}

The tensile strength insignificantly relies on the type and quantity of recycled aggregate applied (especially if the mixture contains only coarse recycled aggregate), yet it depends on an aggregate-concrete content ratio. An increase in that ratio may decrease the tensile strength [56].

Figure 5 shows results of the tensile strength of concentrate mixtures after 7, 14, 28 days. As a result of testing $4 \times 4 \times 16 \mathrm{~cm}$ beams on tensile strength, it was observed that high-strength concrete after 7 days reached $52 \%$ higher strength than recycled aggregate concrete. After 14 days, the difference decreased to $28 \%$, and for the sample tested after 28 days reached $15 \%$. The strength of ordinary concrete is as following: after 7 days $-83 \%$, 14 days - $75 \%$, 28 days - $76 \%$ of recycled aggregate concrete strength. Tukey's significant difference test proved that the results of the tensile strength test of all examined mixtures are significantly different.

In the presented results, the tensile strength after 28 days differed insignificantly and reached: for REC $5 \mathrm{MPa}$, for BWW approximately $6 \mathrm{MPa}$, and BZ approximately 3.5 MPa. Malsey's test proved that the addition of only coarse recycled 


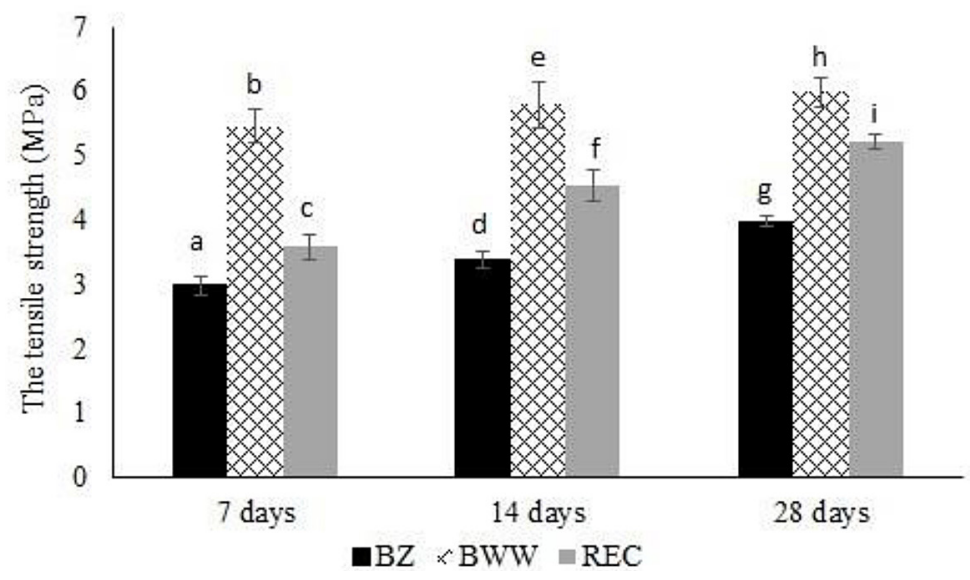

Figure 5. Concrete tensile strength over time

aggregate fraction led to a decrease in the tensile strength up to $10 \%$. It was proved that aggregate containing from $20 \%$ to $50 \%$ of recycled aggregate has the tensile strength lower by $2 \%$ in comparison to concretes from natural aggregate [56]. Etxeberria et al. (2007) attempted to obtain concrete mixtures from recycled aggregate with the same tensile strength as natural aggregate concrete. In mixtures, they replaced natural aggregates in ranges $25 \%, 50 \%$ to $100 \%$. Results revealed that the mixture with $25 \%$ had almost the same tensile and compressive strengths as a control sample - non-additives concrete [20].

Table 8 presents the ratio of tensile strength to compressive strength in mixtures tested after 28 days. Calculations showed that the highest value of coefficient has been reached for ordinary concrete and the lowest for recycled aggregate concrete. That might occur because decreasing the tensile strength of recycled concrete is less susceptible than decreasing the compressive strength of natural aggregate concrete [57].

The interrelation between the tensile strength and the compressive strength of concrete is presented in Figure 6. A high rate of the determination being 0.981 indicates that data has been adjusted by the best R-value. The high value of the determination rate suggests that the tensile strength is in a strong interrelation with the compressive strength. The results are distinctly

Table 8. The ratio of the tensile strength to the compressive strength

\begin{tabular}{|c|c|c|}
\hline Mixtures & $\mathrm{fst} / \mathrm{fc}$ & $\mathrm{fst} / \mathrm{fc}(\%)$ \\
\hline REC & 0.10 & 10.63 \\
\hline BWW & 0.08 & 8.67 \\
\hline BZ & 0.18 & 18.01 \\
\hline
\end{tabular}

grouped, depending on applied concrete. Correlation equation $\mathrm{y}=0.04 \mathrm{x}+3.13$.

\section{Correlation between modulus of rigidity and modulus of elasticity}

As it is presented in Table 6, the greatest value of modulus of rigidity reached natural aggregate concrete, other had approximate values. Statistical analysis proved that values of modulus of rigidity of ordinary and recycled concretes do not statistically differ.

Other researchers' tests show that modulus of elasticity of aggregate from recycled concrete is lower than comparable concrete with natural aggregate, which is a consequence of a considerable amount of old mortar, which has a relatively low level of modulus of elasticity [41, 42]. Researchers suggest that the level of modulus decrease does depend on the type of fine fraction in aggregate mass [52]. In the case of concrete produced entirely from recycled aggregate, the decrease in modulus of elasticity oscillates between $15 \%$ to $45 \%$ concerning natural aggregate concrete. Modulus of elasticity was reported to be negatively affected by incorporation of REC [6, $41,56]$. Kessal et al. reported that the module of elasticity of REC mixtures is lower in comparison with the normal concrete. The reduction is about $20 \%$ with regard to the normal concrete [53].

Figure 7 presents changes of elasticity modulus $\mathrm{E}$ of concrete, depending on the type of concrete and the compressive strength after 28 days. A linear trend was characterised by $\mathrm{R}=0.728$. Obtained correlations may be described by an equation: $y=0.095 x+29.57$.

It is worth noticing that tests proved that the level of difference of elasticity modulus value 


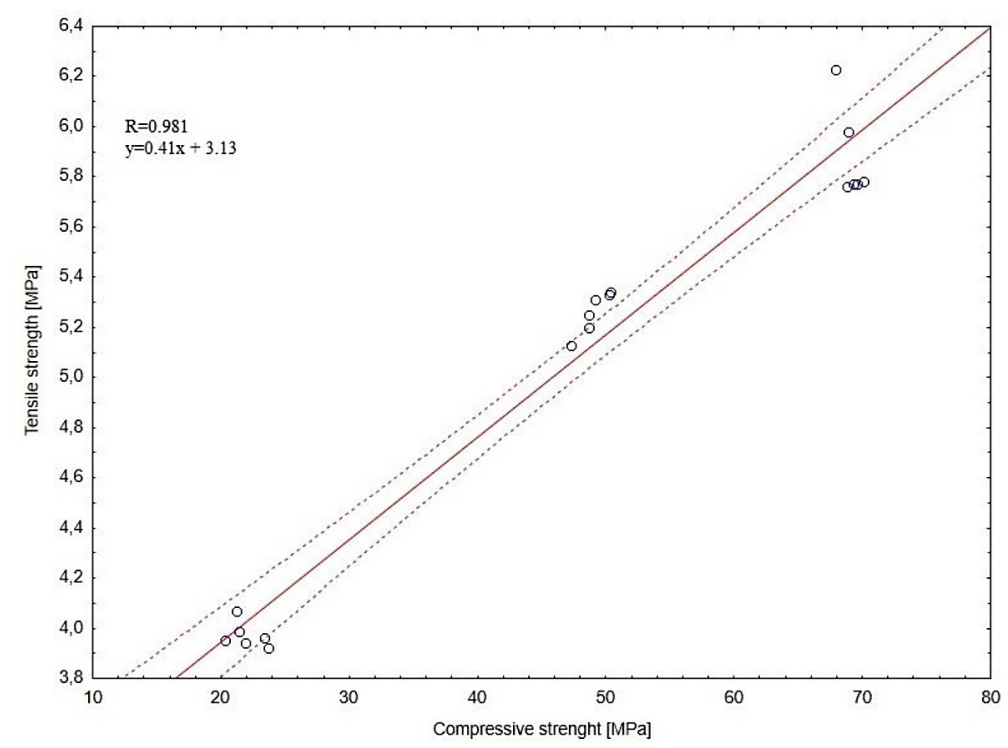

Figure 6. Correlation between tensile strength and compression strength

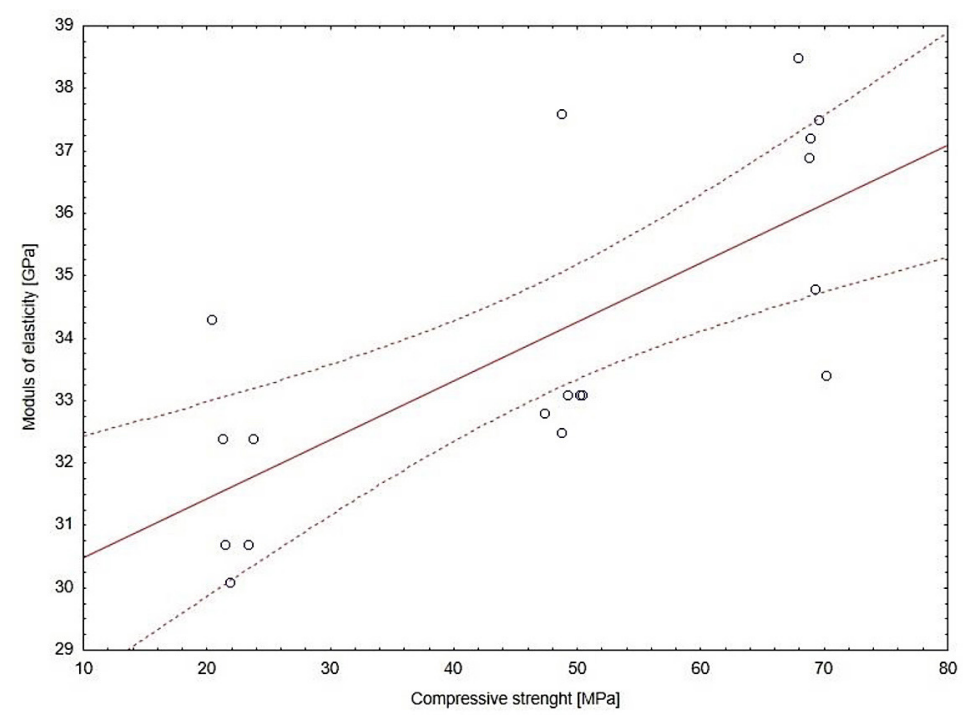

Figure 7. Correlation between compression strength and elastic modulus E of concrete

between recycled concrete and natural aggregate concretes depends also on the compressive strength of tested concretes and for concretes with average values up to $30 \mathrm{MPa}$ the difference of moduli values is almost insignificant, yet with an increase in strength over that values the difference between moduli increases [43]. Table 9 presents values of the ratio of elasticity and rigidity moduli of tested concretes.

The rigidity and elasticity moduli ratio for each tested type of concrete was insignificantly lower than $1 \%$. Tests of dynamic elasticity modulus of concrete proved that both rigidity and elasticity moduli of high-strength concrete are closely approximate and higher approximately $16 \%$ than moduli of recycled aggregate concrete. Rigidity and elasticity moduli of ordinary concrete are lower than REC moduli by $1-2 \%$. The highest value of the ratio of shear strain to the elastic strain of concrete with

Table 9. Correlation rate between elasticity and rigidity moduli

\begin{tabular}{|c|c|c|}
\hline Correlation $\mathrm{B}_{\mathrm{i}, \mathrm{rig} i d i t y} / \mathrm{B}_{\mathrm{i}, \text { elasticity }}$ & $\mathrm{r}$ & $\mathrm{r}[\%]$ \\
\hline $\mathrm{BZ}_{\mathrm{rg}} / \mathrm{BZ}_{\mathrm{el}}$ & 0.99 & 99.20 \\
\hline $\mathrm{BWW}_{\mathrm{rg}} / \mathrm{BWW}_{\mathrm{el}}$ & 0.98 & 98.04 \\
\hline $\mathrm{REC}_{\mathrm{rg}} / \mathrm{REC}_{\mathrm{el}}$ & 0.97 & 97.42 \\
\hline $\mathrm{BWWrg} / \mathrm{RECel}$ & 1.16 & 115.70 \\
\hline $\mathrm{BZrg} / \mathrm{RECel}$ & 0.99 & 99.58 \\
\hline $\mathrm{BWWrg} / \mathrm{RECel}$ & 1.15 & 114.98 \\
\hline $\mathrm{BZrg} / \mathrm{RECel}$ & 0.98 & 97.80 \\
\hline
\end{tabular}


basalt aggregate results from the low elastic strain of that concrete [58].

\section{CONCLUSION}

The presented article aimed at the evaluation of mechanics and strength properties of REC and comparison with ordinary concrete, as well as natural aggregate concrete. From the obtained results following conclusions may be drawn:

1. The compressive strength of cubic samples for the concrete with recycled aggregate (REC) was $31 \%$ lower than that of BWW, but $50 \%$ higher compared to ordinary concrete (BZ).

2. The tensile strength of the concrete with recycled aggregate was $33 \%$ lower than that of BWW and $21 \%$ lower compared ordinary concrete.

3 . Tests of dynamic elasticity modulus of concrete proved that both rigidity and elasticity moduli of high-strength concrete are closely approximate and higher approximately 16\% than moduli of REC. Rigidity and elasticity moduli of ordinary concrete are lower than REC moduli by $1-2 \%$;

4. Statistic analyses proved that values of compressive and tensile strengths are statistically different between tested concretes.

The conducted studies indicated that the adopted method of designing the concrete mix with recycled aggregate is correct and yields measurable results. It was proven that recycled aggregate can be successfully used as a concrete ingredient. Those results emphasise the importance of producing mixtures that may facilitate obtaining a structure of concrete, even containing waste, recycled aggregate characterised by various mechanical properties. Recycled aggregate may become an effective mean for decreasing the impact of construction on the environment, even improving their durability. Furthermore, the combined application of recycled aggregate with mineral waste and alternative bio-natural aggregate $[59,60]$ and structure is an effective approach towards minimalization of the influence of construction on the environment.

\section{Acknowledgments}

This work was financially supported by the Ministry of Science and Higher Education, within the statutory research number WZ/WBIIL/4/2020 and FN-23/IS/2021.

\section{REFERENCES}

1. Ahmed H., Tiznobaik M., Huda S.B., Islam M.S., Alam M.S. Recycled aggregate concrete from large-scale production to sustainable field application. Constr Build Mater. 2020;262:119979. https:// doi.org/10.1016/j.conbuildmat.2020.119979

2. European-Commission, Construction and Demolition Waste [Internet]. [cited 2020 Jan 7]. Available from: http://ec.europa.eu/environment/waste/construction_demolition.htm

3. Statistics Poland. Materials Management in 2018. Warsaw;

4. Tomaszewska J. Polish transition towards circular economy: Materials management and implications for the construction sector. Materials (Basel). 2020;13(22):1-17. https://doi.org/10.3390/ ma13225228

5. Jin R., Li B., Zhou T., Wanatowski D., Piroozfar P. An empirical study of perceptions towards construction and demolition waste recycling and reuse in China. Resour Conserv Recycl. 2017;126(July):86-98. https://doi.org/10.1016/j. resconrec.2017.07.034

6. Kisku N., Joshi H., Ansari M., Panda S.K., Nayak S., Dutta S.C. A critical review and assessment for usage of recycled aggregate as sustainable construction material. Constr Build Mater 2017;131:721-40. http://dx.doi.org/10.1016/j.conbuildmat.2016.11.029

7. Wójcik M., Bąk Ł., Stachowicz F. Unconventional Materials from Sewage Sludge with a Potential Application in a Road Construction. Adv Sci Technol Res J. 2018;12(4):65-75. https://doi. org/10.12913/22998624/99991

8. Borowski G., Świderski T., Ozga M. Stone Dust Agglomeration for Utilizing as Building Material. Adv Sci Technol Res J. 2017, 11(4), 168-74. https://doi.org/10.12913/22998624/79656

9. Wang J., Fang Z., Cai Y., Chai J., Wang P., Geng $\mathrm{X}$. Preloading using fill surcharge and prefabricated vertical drains for an airport. Geotext Geomembranes. 2018;46(5):575-85. https://doi. org/10.1016/j.geotexmem.2018.04.013

10. Rahman M.A., Imteaz M., Arulrajah A., Disfani M.M. Suitability of recycled construction and demolition aggregates as alternative pipe backfilling materials. J Clean Prod. 2014 Mar 1;66:75-84. https://doi.org/10.1016/j.jclepro.2013.11.005

11. Pavlu T., Kocí V., Hájek P. Environmental assessment of two use cycles of recycled aggregate concrete. Sustain. 2019;11(21). https://doi. org $/ 10.3390 /$ su 11216185

12. Johnston R.B. The 2030 Agenda for sustainable development. Res Glob Sustain - Proc 6th Int Congr Arsen Environ AS 2016. 2016;12-4. 
13. Sormunen P., Kärki T. Recycled construction and demolition waste as a possible source of materials for composite manufacturing. J Build Eng. 2019;24(August 2018):100742. https://doi. org/10.1016/j.jobe.2019.100742

14. Özalp F., Yilmaz H.D., Kara M., Kaya Ö., Şahin A. Effects of recycled aggregates from construction and demolition wastes on mechanical and permeability properties of paving stone, kerb and concrete pipes. Constr Build Mater. 2016;110:17-23. https:// doi.org/10.1016/j.conbuildmat.2016.01.030

15. Kaarthik M., Maruthachalam D. A sustainable approach of characteristic strength of concrete using recycled fine aggregate. Mater Today Proc. 2020; (in press). https://doi.org/10.1016/j.matpr.2020.11.058

16. Abbas A., Fathifazl G., Isgor O.B., Razaqpur A.G., Fournier B., Foo S. Environmental benefits of green concrete. 2006 IEEE EIC Clim Chang Technol Conf EICCCC 2006. 2006; (April 2017).

17. Yeheyis M., Hewage K., Shahria Alam M., Eskicioglu C., Sadiq R. An overview of construction and demolition waste management in Canada: a lifecycle analysis approach to sustainabilit. Clean Technol Environ Policy 2013;15:81-91. https:// doi.org/10.1007/s10098-012-0481-6

18. Ozbakkaloglu T., Gholampour A., Xie T. Mechanical and Durability Properties of Recycled Aggregate Concrete: Effect of Recycled Aggregate Properties and Content. J Mater Civ Eng. 2018;30(2):04017275. https://doi.org/10.1061/ (asce)mt.1943-5533.0002142

19. Odd E., Gjorv K.S. Concrete Technology for a Sustainable Development in the 21st Century. 1st Editio. Odd E. Gjorv KS, editor. London: CRC Press; 2014. 400 p.

20. Etxeberria M., Marí A.R., Vázquez E. Recycled aggregate concrete as structural material. Mater Struct Constr. 2007;40(5):529-41. https://doi. org/10.1617/s11527-006-9161-5

21. de Juan M.S., Gutiérrez P.A. Study on the influence of attached mortar content on the properties of recycled concrete aggregate. Constr Build Mater. 2009;23(2):872-7. http://dx.doi.org/10.1016/j.conbuildmat.2008.04.012

22. Silva R.V., De Brito J., Dhir R.K. Establishing a relationship between modulus of elasticity and compressive strength of recycled aggregate concrete. Journal of Cleaner Production. 2016;112:2171-86. https://doi.org/10.1016/j.jclepro.2015.10.064

23. Silva R.V., De Brito J., Dhir R.K. The influence of the use of recycled aggregates on the compressive strength of concrete: A review. Eur J Environ Civ Eng. 2015;19(7):825-49. htt ps://10.1080/19648189.2014.974831

24. Francesconi L, Pani L, Stochino F. Punching shear strength of reinforced recycled concrete slabs. Con- str Build Mater. 2016 Nov 30;127:248-63. https:// doi.org/10.32657/10356/72257

25. Dhir R. Suitability and practicality of using coarse RCA in normal and high-strength concrete. In: 1st International Conference on Sustainable Construction: Waste Management. Singapore; 2004. p. $108-21$.

26. Akbarnezhad A., Ong K.C.G., Zhang M.H., Tam C.T., Foo T.W.J. Microwave-assisted beneficiation of recycled concrete aggregates. Constr Build Mater. 2011;25(8):3469-79. http://dx.doi. org/10.1016/j.conbuildmat.2011.03.038

27. Etxeberria M., Vázquez E., Marí A., Barra M. Influence of amount of recycled coarse aggregates and production process on properties of recycled aggregate concrete. Cem Concr Res. 2007;37(5):735-42. https://doi.org/10.1016/j.cemconres.2007.02.002

28. Limbachiya M., Meddah M. S., Ouchagour Y. Performance of Portland/silica fume cement concrete produced with recycled concrete aggregate. ACI Mater J. 2012;109:91-100. https://doi. org/10.14359/51683574

29. Xiao J.Z., Li J.B., Zhang C. On relationships between the mechanical properties of recycled aggregate concrete: An overview. Mater Struct Constr. 2006;39(6):655-64. https://doi.org/10.1617/ s11527-006-9093-0

30. Elzokra A., Al Houri A., Habib A., Habib M., Malkawi A.B. Shrinkage behavior of conventional and nonconventional concrete: A review. Civ Eng J. 2020;6(9):1839-51. https://doi.org/10.28991/cej2020-03091586

31. 31. Poon C.S., ShuiZ.H., Lam L., Fok H., Kou S.C. Influence of moisture states of natural and recycled aggregates on the slump and compressive strength of concrete. Cem Concr Res. 2004;34(1):31-6. https://doi.org/10.1016/s0008-8846(03)00186-8

32. Rahal K. Mechanical properties of concrete with recycled coarse aggregate. Build Environ. 2007;42(1):407-15. https://doi.org/10.1016/j. buildenv.2005.07.033

33. Tabsh S.W., Abdelfatah A.S. Influence of recycled concrete aggregates on strength properties of concrete. Constr Build Mater. 2009;23(2):1163-7. https://doi.org/10.1016/j.conbuildmat.2008.06.007

34. Lei B., Liu H., Yao Z., Tang Z. Experimental study on the compressive strength, damping and interfacial transition zone properties of modified recycled aggregate concrete. R Soc Open Sci. 2019;6(12). https://doi.org/10.1098/rsos.190813

35. Dilbas H., Şimşek M., Çakir Ö. An investigation on mechanical and physical properties of recycled aggregate concrete (RAC) with and without silica fume. Constr Build Mater. 2014;61(March 2006):50-9. https://doi.org/10.1016/j.conbuildmat.2014.02.057 
36. Joel S. Compressive strength of concrete using fly ash and rice husk ash: A review. Civ Eng J. 2020;6(7):1400-10. https://doi.org/10.28991/cej2020-03091556

37. Aldakshe A., Çağlar H., Çağlar A., Avan Ç. The investigation of use as aggregate in lightweight concrete production of boron wastes. Civ Eng J. 2020;6(7):1328-35. https://doi.org/10.28991/cej2020-03091551

38. González-Fonteboa B., Martínez-Abella F. Concretes with aggregates from demolition waste and silica fume. Materials and mechanical properties. Build Environ. 2008;43(4):429-37. https://doi. org/10.1016/j.buildenv.2007.01.008

39. Pereira P., Evangelista L., De Brito J. The effect of superplasticizers on the mechanical performance of concrete made with fine recycled concrete aggregates. Cem Concr Compos. 2012;34(9):1044-52. http://dx.doi.org/10.1016/j. cemconcomp.2012.06.009

40. Bairagi N.K., Ravande K., Pareek V.K. Behaviour of concrete with different proportions of natural and recycled aggregates. Resour Conserv Recycl. 1993;9(1-2):109-26. https://doi. org/10.1016/0921-3449(93)90036-F

41. Fonseca N., De Brito J., Evangelista L. The influence of curing conditions on the mechanical performance of concrete made with recycled concrete waste. Cem Concr Compos. 2011;33(6):637-43. http:// dx.doi.org/10.1016/j.cemconcomp.2011.04.002

42. Kou S.-C., Poon C.-S. Long-term mechanical and durability properties of recycled aggregate concrete prepared with the incorporation of fly ash. Cem Concr Compos. 2013;37:12-9. https://doi. org/10.1016/j.cemconcomp.2012.12.011

43. Zega C.J., di Maio A.A. Use of recycled fine aggregate in concretes with durable requirements. Waste Manag. 2011;31:2336-2340. https://doi. org/10.1016/j.wasman.2011.06.011

44. https://www.lafarge.pl/cement-cem-iib-v-325-rdisabled-page.

45. Sadowska-Buraczewska B, Barnat-Hunek D, Szafraniec $M$. Influence of recycled high-performance aggregate on deformation and load-carrying capacity of reinforced concrete beams. Materials (Basel). 2020;13(1):186. https://doi.org/10.3390/ ma13010186

46. Sadiqul Islam G.M., Gupta S.D. Evaluating plastic shrinkage and permeability of polypropylene fiber reinforced concrete. Int J Sustain Built Environ. 2016;5(2):345-54. http://dx.doi.org/10.1016/j. ijsbe.2016.05.007

47. Polish standardization committee. esting Hardened Concrete-Part. 3: Compressive Strength of Test Specimens.
48. Polish standardization committee. Testing Hardened Concrete_-Part. 6: Tensile Splitting Strength of Test Specimens.

49. Polish standardization committee. Determination of the Modulus of Elasticity in Compression.

50. Shapiro S.S., Wilk M.B. An analysis of variance test for normality (complete samples). Biometrika. 1965;52:591-611.https://doi.org/10.2307/2333709

51. Bam E.K.P., Akiti T.T., Osae D.S., Ganyaglo S.Y. Gibrilla A. Multivariate cluster analysis of some major and trace elements distribution in an unsaturated zone profile, Densu river basin. African J Environ Sci Technol. 2011;5(3):155-67.

52. Hahladakis J.N., Purnell P., Aljabri H.M.S.J. Assessing the role and use of recycled aggregates in the sustainable management of construction and demolition waste via a mini-review and a case study. Waste Manag Res. 2020;38(4):460-71 https://doi. org/10.1177/0734242X19897816.

53. Kessal O. Performance Study of Eco-Concrete Based on Waste Demolition as Recycled Aggregates. Mater Int. 2020;2(2):123-30. https://doi. org/10.33263/materials22.123130

54. Sagoe-Crentsil K.K., Brown T. Taylor A.H. Performance of Concrete Made with Commercially Produced Coarse Recycled Concrete Aggregate. Cem Concr Res. 2001;31:707-12. https://doi. org/10.1016/S0008-8846(00)00476-2

55. Gómez-Soberón M.J. Porosity of Recycled Concrete with Substitution of Recycled Concrete Aggregate: an experimental study. Cem Concr Res. 2002;32:1301-11. https://doi.org/10.1016/s00088846(02)00795-0

56. Malešev M., Radonjanin V., Marinković S. Recycled concrete as aggregate for structural concrete production. Sustainability. 2010;2(5):1204-25. https://doi.org/10.3390/su2051204

57. Noguchi T., Nemati K.M. Relationship between compressive strength and modulus of elasticity of high-strength concrete. Proc 6th Int ConfFract Mech Concr Concr Struct. 2007;3(August 1995):130511. https://doi.org/10.3130/aijs.60.1_8

58. Piasta W., Budzyński W., Góra J. Wpływ rodzaju kruszywa grubego na odkształcalność betonów zwykłych. Przegląd Bud. 2012;83(7-8):35-8.

59. Sassu M., De Falco A., Giresini L., Puppio M.L. Structural solutions for low-cost bamboo frames: Experimental tests and constructive assessments. Materials (Basel). 2016;9(5). https://doi:10.3390/ ma9050346

60. Pani L., Francesconi L., Rombi J., Mistretta F., Sassu M., Stochino F. Effect of parent concrete on the performance of recycled aggregate concrete. Sustain. 2020;12(22):1-17. https://doi.org/10.3390/ su12229399 